\title{
CYP2D6 Allele Frequency in Five Malaria Vivax Endemic Areas From Brazilian Amazon Region
}

\section{OPEN ACCESS}

Edited by:

J. Kevin Baird,

University of Oxford, United Kingdom

Reviewed by:

Rajeev Kumar Mehlotra,

Case Western Reserve University,

United States

Andre Siqueira,

Instituto Nacional de Infectologia

Evandro Chagas (INI), Brazi

*Correspondence:

Ricardo Luiz Dantas Machado ricardomachado@id.uff.br

Specialty section: This article was submitted to Pharmacogenetics and

Pharmacogenomics,

a section of the journal Frontiers in Pharmacology.

Received: 12 March 2020 Accepted: 07 July 2021 Published: 23 July 2021

Citation:

Salles PF, Perce-da-Silva DS, Rossi $A D$, Raposo $L R$, Ramirez Ramirez $A D$, Pereira Bastos OM, Pratt-Riccio LR, Cassiano GC, Baptista ARS,

Cardoso CC, Banic DM and Machado RLD (2021) CYP2D6 Allele

Frequency in Five Malaria Vivax Endemic Areas From Brazilian Amazon Region.

Front. Pharmacol. 12:542342. doi: 10.3389/fphar.2021.542342
Paula Ferreira Salles ${ }^{1}$, Daiana Souza Perce-da-Silva ${ }^{2}$, Atila Duque Rossi ${ }^{3}$, Luisa Riehl Raposo ${ }^{4}$, Aina Danaisa Ramirez Ramirez ${ }^{1}$, Otílio Machado Pereira Bastos ${ }^{1}$, Lilian Rose Pratt-Riccio ${ }^{5}$, Gustavo Capatti Cassiano ${ }^{6}$, Andrea Regina Souza Baptista ${ }^{1}$, Cynthia Chester Cardoso ${ }^{3}$, Dalma Maria Banic ${ }^{4}$ and Ricardo Luiz Dantas Machado ${ }^{1 *}$

${ }^{1}$ Centro de Investigação de Microrganismos, Universidade Federal Fluminense, Niterói, Brazil, ${ }^{2}$ Faculdade de Medicina de Petrópolis, Petrópolis, Brazil, ${ }^{3}$ Laboratório de Virologia Molecular, Universidade Federal do Rio de Janeiro, Rio de Janeiro, Brazil, ${ }^{4}$ Laboratório de Imunologia Clínica, Instituto Oswaldo Cruz, Fundação Oswaldo Cruz, Rio de Janeiro, Brazil, ${ }^{5}$ Laboratório de Malária, Instituto Oswaldo Cruz, Fundação Oswaldo Cruz, Rio de Janeiro, Brazil, 'Saúde Global e Medicina Tropical, Instituto de Higiene e Medicina Tropical, Universidade de Lisboa, Lisbon, Portugal

Genetic variability was linked with individual responses to treatment and susceptibility to malaria by Plasmodium vivax. Polymorphisms in the CYP2D6 gene may modulate enzyme level and activity, thereby affecting individual responses to pharmacological treatment. The aim of the study was to investigate whether or not CYP2D6 single nucleotide polymorphisms rs1065852, rs38920-97, rs16947 and rs28371725 are unequally distributed in malaria by Plasmodium vivax individuals from the Brazilian Amazon region. The blood samples were collected from 220 unrelated Plasmodium vivax patients from five different endemic areas. Genotyping was performed using SNaPshot ${ }^{\circledR}$ and real-time polymerase chain reaction methods. In all five areas, the rs1065852 (CYP2D6*10, C.100C > T), rs3892097 (CYP2D6*4, 1846C > T) and rs16947 (CYP2D6², C.2850G > A), as a homozygous genotype, showed the lowest frequencies. The rs28371725 (CYP2D6*41, 2988G > A) homozygous genotype was not detected, while the allele $A$ was found in a single patient from Macapá region. No deviations from Hardy-Weinberg equilibrium were found, although a borderline $p$-value was observed ( $p=0.048$ ) for the SNP rs3892097 in Goianésia do Pará, Pará state. No significant associations were detected in these frequencies among the five studied areas. For the SNP rs3892097, a higher frequency was observed for the $\mathrm{C} / \mathrm{T}$ heterozygous genotype in the Plácido de Castro and Macapá, Acre and Amapá states, respectively. The distribution of the CYP2D6 alleles investigated in the different areas of the Brazilian Amazon is not homogeneous. Further investigations are necessary in order to determine which alleles might be informative to assure optimal drug dosing recommendations based on experimental pharmacogenetics.

Keywords: pharmacogenetics, CYP2D6, primaquine, Plasmodium vivax, Genetic polymorphism, relapses 


\section{INTRODUCTION}

Malaria transmission in Brazil is described to hypo-mesoendemic, unstable and with annual seasonal variations (Oliveira-Ferreira et al., 2010). Malaria does not occur homogeneously within the Amazon rain forest, as localities with different levels of transmission have been detected. Plasmodium vivax was responsible for more than 14.3 million malaria cases in the world and $50 \%$ of all malaria cases outside the African continent (Battle et al., 2019). P. vivax malaria is an important public health issue in Brazil, and it accounts for approximately $89 \%$ of clinical cases reported annually (Brasil et al., 2017).

The Brazilian National Malaria Control Program provides guidelines for treatment and also provides free antimalarials. Nowadays, the treatment of choice for $P$. vivax consists of chloroquine diphosphate (at doses of $10 \mathrm{mg}$ base $/ \mathrm{kg}$ on the first day followed by $7.5 \mathrm{mg} / \mathrm{kg}$ on the $2 \mathrm{nd}$ and 3rd days) combined with primaquine diphosphate (at a dose of $0.50 \mathrm{~kg}$ base $/ \mathrm{kg}$ for 7 days), and the second choice is primaquine for 14 days, combined with blood schizontocidal and hypnozoitocidal therapy (Gomes et al., 2015). Parasites that appear in thick blood films and are not detected on the 28 day are considered sensitive. However, the variability of Plasmodium response to antimalarials limits therapeutic success. (Wernsdorfer and Noedl, 2003). Treatment failure may result from resistance of $P$. vivax strains circulating in a given endemic area. In addition, other factors including those intrinsic to the host, the parasite and the antimalarials as well as their interactions contribute to treatment failure (Baird, 2009).

Variability in drug responses among individuals due to genetic factors is associated with polymorphisms of genes encoding drugmetabolizing enzymes

(Chowbay et al., 2005). Cytochrome P450 (CYP) is a superfamily of proteins responsible for metabolizing different substrates. CYP2D6 phase I enzyme is encoded by CYP2D6, a highly polymorphic gene (Moreno et al., 2016) which spans $4.3 \mathrm{~Kb}$ at the 22q13.1 chromosomal region. CYP2D6 alleles are classified according to protein functionality (Llerena et al., 2014; Brasil et al., 2017), and metabolism phenotype prediction has been used to evaluate the risk for treatment failures and to avoid recurrence in different therapeutic protocols (Zhou, 2009; Bennett et al., 2013). The failures of primaquine as an anti-relapse therapy may be attributed to the patient's impaired CYP2D6 metabolizer phenotype (Baird et al., 2018; He et al., 2019). Among the non-functional alleles, CYP2D6 ${ }^{*} 4$ polymorphic variant is prevalent in Caucasians and Africans but is rare in Asians, and encodes for a "none" predicted enzyme activity. CYP2D6 ${ }^{\star} 2$ was referred to encode an enzyme with "normal" activity and its frequencies were previously shown to be homogeneously distributed among distinct Brazilian regions (Friedrich et al., 2014). On the other hand, CYP2D6 $6^{\star} 10$ and CYP2D6 $6^{\star} 41$ are responsible for a reduction in enzyme activity, prevailing in Asian populations (Silvino et al., 2020). Brazil has one of the most diverse populations in the world resulting from five centuries of interethnic breeding between Europeans, Africans and Amerindians (Pena et al., 2011) and all of these CYPs are polymorphic in the Brazilian population (Friedrich et al., 2014). Besides, the Brazilian Amazon presents significant inequality concerning malaria endemicity. The aim of this study was to investigate whether or not CYP2D6 allelic and genotypic frequencies, resulting in three predicted phenotypes, are unequally distributed in $P$. vivax malaria patients from five different Brazilian Amazon areas.

\section{METHODS}

\section{Study Setting}

The study took place from March 2018 to February 2020 and the following design is part of a Dissertation/master's thesis developed at Federal Fluminense University (Salles, 2020). A subset of patients was analyzed of unrelated individuals, previously evaluated by Cavasini et al. (2007) and Cassiano et al. (2015). The endemicity levels of each study area were obtained by the annual parasite index (API), accordingly to Lana et al. (2021) in terms of 1 per 1,000 inhabitants. Likewise, $220-70^{\circ} \mathrm{C}$ frozen peripheral blood samples were analyzed belonging to $P$. vivax infection carriers from five Brazilian malaria endemic areas: Novo Repartimento $(n=57$; API $50-200)$ and Goianésia do Pará, Pará State $(n=80$; API $>200)$; Macapá, Amapá State $(n=44$; API 50-200); Porto Velho, Rondônia State ( $n=21$; API 10-50); and Plácido de Castro, Acre State $(n=18$; API $<10)$ (Figure 1). The patients enrolled in this study complied with the following criteria: they presented clinical malaria symptoms and sought medical assistance, were over 18 years old and had positive results by microscopy (thick film), and infection with $P$. vivax was subsequently confirmed by nested polymerase chain reaction (PCR), followed by signed written informed consent forms. Exclusion criteria included children and adults under 18 years old, pregnancy, related individuals and anti-malarial treatment within the previous 7 days. The study was approved by the Research Ethics Committee (CAAE 06214118.2.0000.5243) from Hospital Universitário Antônio Pedro, Universidade Federal Fluminense.

\section{Single Nucleotide Polymorphisms Genotyping}

Genomic DNA was isolated from peripheral leukocytes by standard procedures, using the phenol-chloroform method. Genomic regions including the CYP2D6 SNPs (rs1065852, rs38920-97 and rs16947) were amplified in a multiplex PCR using QIAGEN Multiplex PCR Kit according to manufacturer's instructions. Briefly, reactions were performed in a final volume of $10 \mu \mathrm{L}$, including $5 \mu \mathrm{L}$ of the MasterMix 2X (final concentration $1 \mathrm{X}$ ), $1 \mu \mathrm{L}$ of DNA at $20 \mathrm{ng} /$ $\mu \mathrm{L}, 2 \mu \mathrm{L}$ of each primer, sense $\left(5^{\prime}-3^{\prime}\right)$ and antisense $\left(3^{\prime}-5^{\prime}\right)$ (Supplementary Table S1) for the different fragments, $2 \mu \mathrm{L}$ of $\mathrm{Q}$ solution and $5 \mu \mathrm{L}$ of sterile nanopure water - QIAGEN, United States). PCR products were purified using Exonuclease I and Shrimp Alkaline Phosphatase $(10 \mu \mathrm{L}$ of the PCR product was added to a 96-well PCR plate on ice. Then, $4.5 \mu \mathrm{L}$ of the enzyme mix was added to each well (SAP $-3.3 \mu \mathrm{L}$; EXO $1-0.13 \mu \mathrm{L}$ and SAP buffer $-1.06 \mu \mathrm{L})$. Specific primers were used for single-base extension using SNaPshot ${ }^{\circledast}$ kit, according to manufacturer's instructions. Reactions were carried out in a final volume of $5.5 \mu \mathrm{L}$, containing $2.5 \mu \mathrm{L}$ of the $\mathrm{SNaPshot}{ }^{\circledR}$ kit, $0.5 \mu \mathrm{L}$ of the primer mix (SNP100, SNP1846 and SNP2850), $1.5 \mu \mathrm{L}$ of purified product and $0.5 \mu \mathrm{L}$ of water (ThermoFisher Scientific, United States). Purified products underwent capillary electrophoresis on an ABI3130 Genetic Analyzer (ThermoFisher 


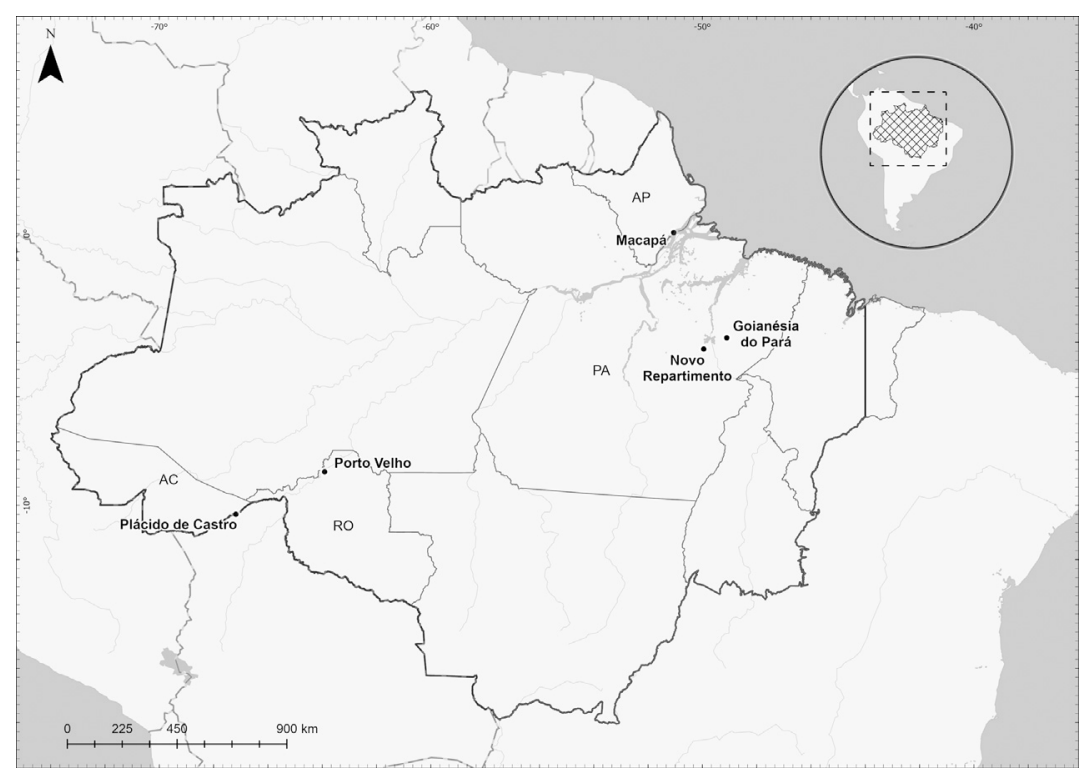

FIGURE 1 | Study area of the CYP2D6 genotyping in the Amazon region of Brazil. Plácido de Castro/Acre State-AC $\left(10^{\circ} 16^{\prime} 33^{\prime \prime} \mathrm{S} ; 67^{\circ} 09^{\prime} 00^{\prime \prime} \mathrm{O}\right)$ is located at the border of Rondônia and Amazonas states, it has a population of 18,235 inhabitants; Porto Velho/Rondônia State - RO $\left(08^{\circ} 45^{\prime} 43^{\prime \prime} \mathrm{S} ; 63^{\circ} 54^{\prime} 14^{\prime \prime} \mathrm{O}\right)$ is the capital of the State of Rondônia in the upper Amazon River basin, with 383,425 inhabitants; Novo Repartimento/Pará State-PA $\left(04^{\circ} 19^{\prime} 50^{\prime \prime} \mathrm{S}\right.$; $\left.49^{\circ} 47^{\prime} 47^{\prime \prime} \mathrm{O}\right)$ is a gold mining area in southeastern Pará State. Its population oscillates and is estimated at around 55,759 habitants; Macapá/Amapá State - AP $\left(00^{\circ} 02^{\prime} 20^{\prime \prime} \mathrm{S}\right.$; $\left.51^{\circ} \mathrm{O} 3^{\prime} 59^{\prime \prime} \mathrm{O}\right)$ is the capital of the state of Amapá and is located by the margins of the Amazon River. Its estimated population is 366,486 inhabitants. (Cavasini et al., 2007). and Goianésia do Pará/ Pará State-PA $\left(03^{\circ} 50^{\prime} 33^{\prime \prime} \mathrm{S} ; 49^{\circ} 05^{\prime} 49^{\prime \prime} \mathrm{O}\right)$, located in the southeastern region of the State of Pará in the north of Brazil. Its population is estimated as 28,583 habitants (Cassiano et al., 2015). The climate in these areas is characterized as tropical with no dry season; the mean monthly precipitation level is at least $60 \mathrm{~mm}$. The samples were recruited at the respective Malaria Diagnosis Centers.

Scientific, United States) using the standard fragment analysis protocol. GeneMapper software (version 4.0 Thermo Scientific, Massachusetts, United States) was used for genotyping. Primers used for PCR amplification and $\mathrm{SNaPshot}{ }^{\circledR}$ reactions are detailed in Supplementary Table S1.

SNP rs28371725 was genotyped by real-time PCR using a custom rhAmp ${ }^{\circledast}$ genotyping assay, according to manufacturer's instructions (Integrated DNA Technologies, United States). Reactions were run on a 7,500 Real-time PCR system (ThermoFisher Scientific, United States) using the standard genotyping protocol.

\section{Statistical Analysis}

Statistical analyses were performed in R environment, using the "gap" packages, $\chi^{2}$ tests were performed to assess possible deviations from the Hardy-Weinberg equilibrium. Chi-square test was also performed to compare the CYP2D6 allele and genotype among regions. Frequencies of each SNP were compared among the malaria endemic areas using Fisher's exact tests and logistic regression models. A $p$-value $\leq 0.05$ was considered statistically significant.

\section{RESULTS}

Genotypic and allele frequencies of CYP2D6 SNPs were successfully genotyped in $93 \%$ of the samples (Table 1). In all five areas, SNPs rs1065852 (CYP2D6*10, C.100C > T), rs3892097 $\left(\right.$ CYP2D6*4, C.1846C > T), rs16947 $\left(\right.$ CYP2D6 $^{\star} 2$, C.2850G > A) were found in low frequencies, mainly in heterozygosity. Notably, allele $A$ at rs28371725 (CYP2D6*41) was found in a single patient from Macapá region, also as a heterozygous genotype. The wild-type alleles $\mathrm{C}$ and $\mathrm{G}$, respectively, were highly frequent in all areas. No significant associations were detected in these frequencies among the five studied areas. For the SNP rs3892097 (CYP2D6*4, C.1846C > T), a higher frequency was observed for the $\mathrm{C} / \mathrm{T}$ heterozygous genotype in Plácido de Castro, Acre state and Macapá, Amapá state. The polymorphic allele $\mathrm{T}$ was detected in a higher frequency in these areas. All SNPs were at Hardy-Weinberg equilibrium in all areas (all $p$ values $>0.05$ ) except for the SNP rs3892097 (CYP2D6*4, C.1846C > T) in Goianésia do Pará, Pará state $(p=0.048)$.

Table 2 summarizes the findings from five previous studies in which CYP2D6 variants ${ }^{\star} 2,{ }^{\star} 4,{ }^{\star} 10$ and ${ }^{\star} 41$ frequencies were described for populations from distinct Brazilian regions and those from the present study. Overall, CYP2D6 ${ }^{\star} 2$ allele frequencies in all five areas from the Amazon region are less frequent than those obtained in other regions from the country. Other studies have shown higher frequencies for the CYP2D $6^{\star} 41$ allele in comparison to the observed for the $P$. vivax patients populations, since only one individual in one of the regions carried this variant. A wide variation was observed for the CYP2D6 ${ }^{\star} 10$ allele frequencies within the 5 distinct Brazilian Amazon regions, a phenomena also verified among the other Brazilian regions. In the present study, the CYP2D6*4 allele frequencies were higher than those detected for the majority of other populations. 
TABLE 1 | Distribution of genotype and allele frequencies along with confidence intervals among the study areas.

\begin{tabular}{|c|c|c|c|c|c|c|c|}
\hline \multirow[t]{2}{*}{ SNP } & \multirow{2}{*}{$\begin{array}{l}\text { Genotype/ } \\
\text { allele }\end{array}$} & \multicolumn{5}{|c|}{ Study areas } & \multirow[t]{2}{*}{$p$-value ${ }^{a}$} \\
\hline & & PLC $(n=18)$ & PVL $(n=21)$ & $\operatorname{NRP}(n=57)$ & MCP $(n=44)$ & GNP $(n=80)$ & \\
\hline \multirow[t]{5}{*}{$\begin{array}{l}\text { CYP2D6*10 rs1065852 } \\
(100 \mathrm{C}>\mathrm{T})\end{array}$} & $\mathrm{C} / \mathrm{C}$ & $\begin{array}{l}16 \text { (88.9\%) } \\
95 \% \text { Cl: } 65.2-98.6 \%\end{array}$ & $\begin{array}{l}16 \text { (76.2\%) } \\
95 \% \mathrm{Cl}: 52.8-91.8 \%\end{array}$ & $\begin{array}{l}40 \text { (70.2\%) } \\
95 \% \mathrm{Cl}: 56.6-81.6 \text { and }\end{array}$ & $\begin{array}{l}36 \text { (81.8\%) } \\
95 \% \mathrm{Cl}: 67.3-91.8 \%\end{array}$ & $\begin{array}{l}64(80 \%) \\
95 \% \mathrm{Cl}: 69.6-88.1 \%\end{array}$ & 0.7681 \\
\hline & $\mathrm{C} / \mathrm{T}$ & $\begin{array}{l}2(11.1 \%) \\
95 \% \mathrm{Cl}: 1.4-34.7 \%\end{array}$ & $\begin{array}{l}4(19.0 \%) \\
95 \% \mathrm{Cl}: 5.4-41.9 \%\end{array}$ & $\begin{array}{l}15 \text { (26.3\%) } \\
95 \% \text { Cl: } 15.5-39.7 \%\end{array}$ & $\begin{array}{l}7 \text { (15.9\%) } \\
95 \% \mathrm{Cl}: 6.6-30 \%\end{array}$ & $\begin{array}{l}15 \text { (18.7\%) } \\
95 \% \mathrm{Cl}: 10.9-29 \%\end{array}$ & - \\
\hline & $\mathrm{T} / \mathrm{T}$ & $\begin{array}{l}0(0 \%) \\
95 \% \mathrm{Cl}: 0.0-18.5 \%\end{array}$ & $\begin{array}{l}1(4.8 \%) \\
95 \% \mathrm{Cl}: 0.1-23.8 \%\end{array}$ & $\begin{array}{l}2(3.5 \%) \\
95 \% \mathrm{Cl}: 0.4-12.1 \%\end{array}$ & $\begin{array}{l}1(2.3 \%) \\
95 \% \mathrm{Cl}: 0.06-12 \%\end{array}$ & $\begin{array}{l}1(1.3 \%) \\
95 \% \mathrm{Cl}: 0.03-6.8 \%\end{array}$ & - \\
\hline & Allele C & $\begin{array}{l}34 \text { (94.4\%) } \\
95 \% \mathrm{Cl}: 81.3-99.3 \%\end{array}$ & $\begin{array}{l}36 \text { (85.7\%) } \\
95 \% \mathrm{Cl}: 71.5-94.6 \%\end{array}$ & $\begin{array}{l}95 \text { (83.3\%) } \\
95 \% \text { Cl: } 75.2-89.7 \%\end{array}$ & $\begin{array}{l}79 \text { (89.8\%) } \\
95 \% \text { Cl: 81.5-95.2\% }\end{array}$ & $\begin{array}{l}143(89.4 \%) \\
95 \% C l: 83.5-93.7 \%\end{array}$ & 0.3417 \\
\hline & $\begin{array}{l}\text { Allele T } \\
\text { HWE }\end{array}$ & $\begin{array}{l}34(94.4 \%) \\
95 \% \mathrm{Cl}: 0.7-18.7 \% \\
1\end{array}$ & $\begin{array}{l}6(14.3 \%) \\
95 \% \mathrm{Cl}: 5.4-28.5 \% \\
0.338\end{array}$ & $\begin{array}{l}19(16.7 \%) \\
95 \% \mathrm{Cl}: 10.3-24.8 \% \\
0.6383\end{array}$ & $\begin{array}{l}9(10.2 \%) \\
95 \% \mathrm{Cl}: 4.8-18.5 \% \\
0.3647\end{array}$ & $\begin{array}{l}17(10.6 \%) \\
95 \% \text { Cl: } 6.3-16.5 \% \\
1\end{array}$ & - \\
\hline \multirow[t]{6}{*}{$\begin{array}{l}\text { CYP2D6*4 rs3892097 } \\
(1846 \mathrm{C}>\mathrm{T})\end{array}$} & $\mathrm{C} / \mathrm{C}$ & $\begin{array}{l}8 \text { (44.4\%) } \\
95 \% \text { Cl: } 21.5-69.2 \%\end{array}$ & $\begin{array}{l}11(52.4 \%) \\
95 \% \mathrm{Cl}: 29.8-74.2 \%\end{array}$ & $\begin{array}{l}28(49.1 \%) \\
95 \% \text { Cl: } 35.6-62.7 \%\end{array}$ & $\begin{array}{l}19 \text { (43.2\%) } \\
95 \% \mathrm{Cl}: 28.3-59 \%\end{array}$ & $\begin{array}{l}38(47.5 \%) \\
95 \% \mathrm{Cl}: 36.2-59 \%\end{array}$ & 0.5193 \\
\hline & $\mathrm{C} / \mathrm{T}$ & $\begin{array}{l}9 \text { (50.0\%) } \\
95 \% \mathrm{Cl}: 26-74 \%\end{array}$ & $\begin{array}{l}9 \text { (42.9\%) } \\
95 \% \mathrm{Cl}: 21.8-65.9 \%\end{array}$ & $\begin{array}{l}21(36.8 \%) \\
95 \% \mathrm{Cl}: 24.4-50.6 \%\end{array}$ & $\begin{array}{l}22(50 \%) \\
95 \% C l: 34.6-65.4 \%\end{array}$ & $\begin{array}{l}28(35 \%) \\
95 \% \text { Cl: } 24.7-46.5 \%\end{array}$ & - \\
\hline & $\mathrm{T} / \mathrm{T}$ & $\begin{array}{l}1(5.6 \%) \\
95 \% \mathrm{Cl}: 0.1-27.3 \%\end{array}$ & $\begin{array}{l}1(4.8 \%) \\
95 \% \mathrm{Cl}: 0.1-23.8 \%\end{array}$ & $\begin{array}{l}8 \text { (14\%) } \\
95 \% \text { Cl: } 6.3-25.8\end{array}$ & $\begin{array}{l}3 \text { (6.8\%) } \\
95 \% \mathrm{Cl}: 1.4-18.7 \%\end{array}$ & $\begin{array}{l}14(17.5 \%) \\
95 \% \text { Cl: } 9.9-27.6 \%\end{array}$ & - \\
\hline & Allele C & $\begin{array}{l}25 \text { (69\%) } \\
95 \% \text { Cl: 51.9-83.6\% }\end{array}$ & $\begin{array}{l}31(74 \%) \\
95 \% \mathrm{Cl}: 58-86.1 \%\end{array}$ & $\begin{array}{l}77(68 \%) \\
95 \% \mathrm{Cl}: 58.1-76 \%\end{array}$ & $\begin{array}{l}60(68 \%) \\
95 \% \text { Cl: } 57.4-77.7 \%\end{array}$ & $\begin{array}{l}104(65 \%) \\
95 \% C l: 57.1-72.4 \%\end{array}$ & 0.8616 \\
\hline & Allele T & $\begin{array}{l}11(31 \%) \\
95 \% \text { Cl: } 16.3-48.1 \%\end{array}$ & $\begin{array}{l}11(26 \%) \\
95 \% \mathrm{Cl}: 13.9-42 \%\end{array}$ & $\begin{array}{l}37(32 \%) \\
95 \% \mathrm{Cl}: 24-41.9 \%\end{array}$ & $\begin{array}{l}28(32 \%) \\
95 \% \text { Cl: } 22.3-42.6 \%\end{array}$ & $\begin{array}{l}56(35 \%) \\
95 \% \mathrm{Cl}: 27.6-42.9 \%\end{array}$ & - \\
\hline & HWE & 1 & 1 & 0.233 & 0.488 & 0.048 & - \\
\hline \multirow[t]{6}{*}{$\begin{array}{l}\text { CYP2D6*2 rs16947 } \\
(2850 \mathrm{G}>\mathrm{A})\end{array}$} & $\mathrm{G} / \mathrm{G}$ & $\begin{array}{l}16 \text { (88.9\%) } \\
95 \% \text { Cl: } 65.3-98.6 \%\end{array}$ & $\begin{array}{l}15 \text { (71.4\%) } \\
95 \% \mathrm{Cl}: 47.8-88.7 \%\end{array}$ & $\begin{array}{l}42 \text { (73.7\%) } \\
95 \% \mathrm{Cl}: 60.3-84.5 \%\end{array}$ & $\begin{array}{l}37 \text { (84.1\%) } \\
95 \% \mathrm{Cl}: 69.9-93.5 \%\end{array}$ & $\begin{array}{l}65 \text { (81.2\%) } \\
95 \% \mathrm{Cl}: 71-89.1 \%\end{array}$ & 0.8048 \\
\hline & $\mathrm{G} / \mathrm{A}$ & $\begin{array}{l}2(11.1 \%) \\
95 \% \mathrm{Cl}: 1.4-34.7 \%\end{array}$ & $\begin{array}{l}5 \text { (23.8\%) } \\
95 \% \mathrm{Cl}: 8.2-47.2 \%\end{array}$ & $\begin{array}{l}13(22.8 \%) \\
95 \% \mathrm{Cl}: 12.7-35.8 \%\end{array}$ & $\begin{array}{l}6(13.6 \%) \\
95 \% \mathrm{Cl}: 5.2-24.3 \%\end{array}$ & $\begin{array}{l}14(17.5 \%) \\
95 \% \mathrm{Cl}: 9.9-27.6 \%\end{array}$ & - \\
\hline & $\mathrm{A} / \mathrm{A}$ & $\begin{array}{l}0 \\
95 \% \mathrm{Cl}: 0-18.5 \%\end{array}$ & $\begin{array}{l}1(4.8 \%) \\
95 \% \mathrm{Cl}: 0.1-23.8 \%\end{array}$ & $\begin{array}{l}2(3.5 \%) \\
95 \% \mathrm{Cl}: 0.4-12.1 \%\end{array}$ & $\begin{array}{l}1(2.3 \%) \\
95 \% \mathrm{Cl}: 0.06-12 \%\end{array}$ & $\begin{array}{l}1(1.2 \%) \\
95 \% \mathrm{Cl}: 0.03-6.8 \%\end{array}$ & - \\
\hline & Allele G & $\begin{array}{l}34 \text { (94.4\%) } \\
\text { 95\%Cl: 81.3-99.3\% }\end{array}$ & $\begin{array}{l}35 \text { (83.3\%) } \\
95 \% \text { Cl: 68.6-93\% }\end{array}$ & $\begin{array}{l}97 \text { (85.1\%) } \\
95 \% \text { Cl: } 77.2-91.1 \%\end{array}$ & $\begin{array}{l}80 \text { (90.9\%) } \\
95 \% \text { Cl: 82.9-95.6\% }\end{array}$ & $\begin{array}{l}144 \text { (90\%) } \\
95 \% \text { Cl: } 84.3-94.2 \%\end{array}$ & 0.3366 \\
\hline & Allele A & $\begin{array}{l}2 \text { (5.6\%) } \\
95 \% \mathrm{Cl}: 0.7-18.7 \%\end{array}$ & $\begin{array}{l}7 \text { (16.7\%) } \\
95 \% \mathrm{Cl}: 7-31.4 \%\end{array}$ & $\begin{array}{l}17 \text { (14.9\%) } \\
95 \% \mathrm{Cl}: 8.9-22.8 \%\end{array}$ & $\begin{array}{l}8 \text { (9.1\%) } \\
95 \% \mathrm{Cl}: 4-17.1 \%\end{array}$ & $\begin{array}{l}16 \text { (10\%) } \\
95 \% \mathrm{Cl}: 5.8-15.7 \%\end{array}$ & - \\
\hline & HWE & 0.448 & 0.59 & 0.294 & 0.564 & 0.448 & - \\
\hline \multirow[t]{7}{*}{ CYP2D6*41 rs28371725 (2988 G > A) } & $\mathrm{G} / \mathrm{G}$ & $\begin{array}{l}16 \text { (100\%) } \\
95 \% \text { Cl: } 79.4-100 \%\end{array}$ & $\begin{array}{l}15 \text { (100\%) } \\
95 \% \text { Cl: } 78.2-100 \%\end{array}$ & $\begin{array}{l}42 \text { (100\%) } \\
95 \% \mathrm{Cl}: 91.6-100 \%\end{array}$ & $\begin{array}{l}43(97.73 \%) \\
95 \% \mathrm{Cl}: 88-100 \%\end{array}$ & $\begin{array}{l}65 \text { (100\%) } \\
95 \% \text { Cl: } 94.5-100 \%\end{array}$ & n.d \\
\hline & $\mathrm{G} / \mathrm{A}$ & $0(0 \%)$ & $0(0 \%)$ & $0(\%)$ & $\begin{array}{l}1(2.27 \%) \\
95 \% \mathrm{Cl}: 0.06-12 \%\end{array}$ & $0(\%)$ & - \\
\hline & $\mathrm{A} / \mathrm{A}$ & $0(0 \%)$ & $0(0 \%)$ & $0(\%)$ & $0(0 \%)$ & $0(0 \%)$ & - \\
\hline & Alleles & - & - & - & - & - & - \\
\hline & $G$ & $\begin{array}{l}32 \text { (100\%) } \\
95 \% \text { Cl: } 89.1-100 \%\end{array}$ & $\begin{array}{l}30 \text { (100\%) } \\
95 \% \mathrm{Cl}: 88.4-100 \%\end{array}$ & $\begin{array}{l}84 \text { (100\%) } \\
95 \% \mathrm{Cl}: 95.7-100 \%\end{array}$ & $\begin{array}{l}87 \text { (98.86\%) } \\
95 \% \mathrm{Cl}: 93.8-100 \%\end{array}$ & $\begin{array}{l}130(100 \%) \\
95 \% \mathrm{Cl}: 97.2-100 \%\end{array}$ & n.d \\
\hline & A & $0(0 \%)$ & $0(0 \%)$ & $0(\%)$ & $\begin{array}{l}1(1.14 \%) \\
95 \% \mathrm{Cl}: 0.03-6.2 \%\end{array}$ & $0(0 \%)$ & - \\
\hline & HWE & n.d & n.d & n.d & 1 & n.d & - \\
\hline
\end{tabular}

Frequencies were determined by direct counting considering the total number of subjects genotyped from each region. Confidence intervals were estimated using the Clopper-Pearson exact method.

${ }^{a} \mathrm{p}$ values were determined for comparisons between genotype distributions of the different areas using a Chi-square test.

PLC = Plácido de Castro; PVL = Porto Velho; NRP Novo Repartimento; MCP = Macapá; GNP = Goianésia do Pará.

$H W E=$ Hardy-Weinberg equilibrium (p-value). 


\section{DISCUSSION}

One of the main treatment challenges in P. vivax malaria is to achieve an effective and safe radical cure for the patient, since the frequent relapse episodes, caused by activation of hypnozoites, are extremely difficult to control due to the absence of biomarkers for diagnosis and detection of latent forms (Brasil et al., 2018). In addition, refractory to most antimalarial drugs, hypnozoites are difficult to eradicate, as they can only be removed by treatment with primaquine, which may have its effectiveness reduced due to altered metabolism of CYP2D6 (Bennett et al., 2013; Pybus et al., 2013). At this point, the pharmacokinetic understanding of primaquine is very important to optimize the therapeutic dosage regimen and reduce infectivity to mosquitoes, by reactivating hypnozoites. It is now known that for CYP2D6 there are more than 150 major allelic variants (Baird et al., 2018) and large populations of individuals in endemic areas of malaria are believed to be affected by null or intermediate phenotypes of this enzyme (Bains, 2013).

In the present study we chose to report CYP2D6 polymorphisms based not solely on previous published frequencies but also to provide a scenario of its allele's encoding for three predicted phenotypes: "none," poor metabolizer and "normal" enzyme activities in $P$. vivax malaria patients from five different Brazilian Amazon areas. The CYP2D $6^{*} 4$ allele is more common in populations with a marked European contribution (Crews et al., 2014). In our study, higher frequencies of the heterozygous genotype were found in two municipalities from both Western and Eastern borders of the Brazilian Amazon (Figure 1). This high frequency of $\mathrm{CYP}_{2} \mathrm{D}^{\star} 4$, in populations in Macapá, state of Amapá and in Plácido de Castro, stare of Acre, can be explained by genetic drift and bottlenecks (Griman et al., 2012). Additionally, the frequency of the CYP2D6*4 allele is relatively high in Hispanic populations (Naranjo, et al., 2016), resulting from the Spanish component in the population of Plácido de Castro, since the state of Acre belonged to Bolivia and was incorporated into Brazil about 100 years ago (Machado et al., 2004). The same may have occurred in the state of Amapá, which has a continuous immigration of people from French Guiana, whose population has a predominantly European background (Gomes et al., 2015). Interestingly, the $\mathrm{C}>\mathrm{T}$ rs3892097 polymorphism, that characterizes the allele, is not in Hardy-Weinberg equilibrium in the population of Goianésia do Pará, suggesting its introduction by intense
Migratory flow resulting, from the extensive regional gold mining economic activity. Another possibility is that CYP2D6 participates in the metabolism of countless xenobiotics and, therefore, has diverse metabolic outcomes with distinct selection pressures over this allele (Silveira et al., 2009b). We cannot rule out the possibility that both mechanisms occur in parallel, characterizing an ongoing process of CYP2D6 metabolic peculiarity in the population of this area. It is important to point out to professionals involved in Public Health, especially in malaria control, that the high frequency of $\mathrm{CYP}_{2} \mathrm{D}^{\star} 4$ in Goianésia do Pará, PA, (about $1 / 3$ of the population) results in a chance of relapse during treatment with the current therapeutic protocol since carrying this polymorphism results in a poor metabolizer phenotype. Consequently, individuals treated with the currently established doses of primaquine could present diminished serum levels of active metabolites and, consequently, therapeutic failure.

Furthermore, in a previous study in the Rio Pardo agricultural settlement (Amazon region), P. vivax malaria patients were enrolled to investigate recurrence and the most common CYP2D6 diplotypes predicting reduced metabolism were ${ }^{\star} 2 /{ }^{\star} 4$ (normal-slow metabolizers; Silvino et al., 2020). In spite of the fact that this analysis was not performed in the present study, a limitation we acknowledge, it would be of great interest to investigate the prevalence of the ${ }^{\star} 2{ }^{\star} 4$ diplotypes in the malaria exposed populations, mainly in Macapá and Goianésia do Pará.

CYP2D6 ${ }^{\star} 10$ is a variation originating in Asian populations (Crews et al., 2014; Dorji et al., 2019) varying from 3.8 to 5.6\%, in East Asian countries (Hoskins et al., 2005). Previously, a low frequency of this allele was reported in non-malarial Amerindian populations in Venezuela (Moreno et al., 2016) and among healthy individuals in Northern Brazil (Friedrich et al., 2014), as documented in the present study. In addition, two studies with malarial populations in the municipality of Cuiabá, in the state of Mato Grosso, (Silvino et al., 2016), and in Manaus, state of Amazonas (Brasil et al., 2018) demonstrated the same profile. In fact, the frequencies verified in the present study $(0-4.8 \%)$ is are expected since, previously, our group reported the estimate of the Amerindian ethnic contribution to the populations of Porto Velho (TarazonaSantos et al., 2011) and Goianésia do Pará (Cassiano et al., 2015), estimating percentages of 28 and $24.5 \%$, respectively.

The substitution G2988A occur in an intronic region and are associated with a splicing defect, leading to a lower expression of the enzyme by quantitatively modulating the splicing events around exon/intron 6 (Toscano et al., 2006). Few investigations have

TABLE 2 | Frequency distribution of CYP2D6 alleles in distinct populations according to Brazilian regions.

\begin{tabular}{|c|c|c|c|c|c|c|}
\hline \multirow{2}{*}{$\begin{array}{l}\text { Author } \\
-\end{array}$} & \multirow{2}{*}{$\frac{\text { Brazilian region }}{-}$} & \multirow{2}{*}{$\begin{array}{c}\text { Population } \\
-\end{array}$} & \multicolumn{4}{|c|}{ CYP2D6 allele frequencies } \\
\hline & & & *2 & *4 & ${ }^{*} 10$ & *41 \\
\hline Silveira et al (2009a) & Southeast & Children LLA & - & 0.1316 & - & - \\
\hline Silveira et al (2009b) & Southeast & Hospital & - & $0.0955-0.909$ & - & - \\
\hline Antunes et al. (2012) & Southern & Breast cancer & 0.1753 & 0.1443 & 0.0103 & 0.0412 \\
\hline Friedrich et al (2014) & Four regions & Healthy & 0.215 & 0.094 & 0.0205 & 0.055 \\
\hline \multirow[t]{2}{*}{ Kohlrausch et al (2009) } & Southern & Healthy & $0.125-0.1265$ & $0.0632-0.1033$ & $0.272-0.402$ & $0.0707-0.1092$ \\
\hline & Southern & Schizophrenic & 0.182 & 0.1318 & 0.215 & 0.833 \\
\hline Current study & Northern (5 areas) & P. vivax patients & $0.056-0.149$ & $0.310-0.350$ & $0.056-0.167$ & $0-0.011$ \\
\hline
\end{tabular}

LLA-Acute Lymphoblastic Leukemia 
addressed the frequency of $C Y P 2 D 6^{\star} 41$ in malaria populations in Brazil (Silvino et al., 2018; Brasil et al., 2018). In the present study a very low frequency of this SNP was found, as previously detected in a Brazilian population (Antunes et al., 2012). Initially, this allele was reported as common in populations from West and South Asia (Crews et al., 2014). However, recently, Rodrigues-Soares et al. (2020) showed that this rare allele, whose frequency varies between 0 and $16.2 \%$ among Ibero-American populations, has a stronger association with continental ancestry, as predicted by its European ancestry.

Taken together, the $C Y P 2 \mathrm{D} 6^{\star} 10, C Y P 2 \mathrm{D} 6^{\star} 2$, and $C Y P 2 \mathrm{D} 6^{\star} 41$ frequencies in the five areas of the Brazilian Amazon suggest that they may not affect primaquine metabolism and, if so, ultimately, would not influence episodes of malaria relapses. Previous studies among Brazilian populations revealed that polymorphisms in CYP2D6 are implicated in primaquine treatment failure and may, in part, explain $P$. vivax relapses (Silvino et al., 2016, 2020; Brasil et al., 2018; Daher et al., 2019). Recently, Silvino and co-authors (2020) showed that time of exposure to malaria modulates the risk of $P$. vivax recurrence, adding new evidence on the immune status as an additional variable to be considered. These data reinforce the fact that $P$. vivax malaria should not be considered as a unique entity in the largest endemic region of the Americas.

Equally important is the elimination of mature $P$. falciparum gametocytes (less than $10 \%$ of the malaria cases in Brazil) by primaquine, since CYP2D6 activity may also impact the treatment of this species, ultimately influencing malaria transmission profiles in endemic areas. Indeed, substantial variation in the frequencies of the CYP2D6 alleles may have a major effect on the current malaria treatment protocol outcomes. Finally, if $C Y P 2 \mathrm{D}^{\star} 4$ alters the risk of $P$. vivax malaria relapses, it can also set a barrier to the success of this disease control program in Brazil.

In addition, the distribution of the CYP2D6 alleles investigated in the different areas of the Brazilian Amazon is not homogeneous. This is a major concern once $90 \%$ of all malaria cases in Brazil are caused by $P$. vivax. Since the alleles investigated in the present study do not comprise the full range of the CYP2D6 genetic variability, future prospective studies must be conducted. Among them, the clinical impact of CYP2D6-dependent metabolism of primaquine should be included to respond whether the Brazilian national malaria control program can establish genetic-based strategies to monitor subpopulations at greater risk for malaria relapse. Indeed, the association of more complex approaches such as haplotype/diplotype descriptions, CYP copy number and gene expression, and serum drug level dosages in distinct Brazilian Amazon populations are needed in order to assure optimal dosing recommendations based on experimental pharmacogenetics. Further investigations will be able to determine which alleles might be informative. If so, these must also address the potential association CYP2D6 polymorphisms to other factors such as adherence, drug quality, and parasite tolerance plus incidence and recurrence of infections. Altogether these data will assure optimal drug dosing recommendations based on experimental pharmacogenetics.

\section{DATA AVAILABILITY STATEMENT}

The datasets generated for this study can be found in the dbSNP, dbVar, European Variation Archive, DGVa. Requests to access the datasets should include a letter indicating the intended use and appropriate approval by your institution. This should be directed to the corresponding author.

\section{ETHICS STATEMENT}

The study was approved by the Research Ethics Committee (CAAE 06214118.2.0000.5243) from Hospital Universitário Antônio Pedro, Universidade Federal Fluminense. The patients/participants provided their written informed consent to participate in this study.

\section{AUTHOR CONTRIBUTIONS}

Conceived and designed the experiments: DB, DS, CC, RM. Performed the experiments: PS, LR, AR, LR, AR, OB, DS. Analyzed the data: GC, CC, DS, AB, RM. Contributed reagents/materials/analysis tools: $\mathrm{DB}, \mathrm{CC}, \mathrm{RM}$. Wrote the paper: PS, DB, DS, AB, CC, RM. Revised the manuscript critically: PS, DB, LR, AB, CC and RM. All authors read and approved of the final manuscript.

\section{FUNDING}

Work reported in this manuscript was funded in part by Conselho Nacional para o Desenvolvimento Científico e Tecnológico (CNPq), Brasília, Brazil-CNPq (Grant 306767/ 2018-0 to RLDM; Grant 404068/2012-0 to DMB, Grant E-26/ 202.791/2019 to CCC), and in part by Fundação de Amparo à Pesquisa do Estado do Rio de Janeiro, Brazil-FAPERJ (Grant E_26/202.808/2017-232679 to RLDM; Grant E-26/202.791/2019 to CCC). ARB and RLDM are supported by a CNPq Fellowship.

\section{ACKNOWLEDGMENTS}

We acknowledge the participants in the study, without whom this research could not have been done. For laboratorial support the authors wish to show their appreciation to Gabriel Barbosa de Abreu (in memorian). To Norman Ratcliffe for the English revision of this manuscript. Part of this work is described in a Master's Dissertation by PS, conducted at the Applied Microbiology and Parasitology Post-graduation Program, Federal Fluminense University.

\section{SUPPLEMENTARY MATERIAL}

The Supplementary Material for this article can be found online at: https://www.frontiersin.org/articles/10.3389/fphar.2021.542342/ full\#supplementary-material 


\section{REFERENCES}

Antunes, M. V., Linden, R., Santos, T. V., Wallemacq, P., Haufroid, V., Classen, J.F., et al. (2012). Endoxifen Levels and its Association with CYP2D6 Genotype and Phenotype. Ther. Drug Monit. 34 (4), 422-431. doi:10.1097/ FTD.0b013e318260b46e

Bains, R. K. (2013). African Variation at Cytochrome P450 Genes: Evolutionary Aspects and the Implications for the Treatment of Infectious Diseases Evol. Med. Public Health 2013 (1), 118-134. doi:10.1093/emph/eot010

Baird, J. K., Louisa, M., Noviyanti, R., Ekawati, L., Elyazar, I., Subekti, D., et al. (2018). Association of Impaired Cytochrome P450 2D6 Activity Genotype and Phenotype with Therapeutic Efficacy of Primaquine Treatment for Latent Plasmodium Vivax Malaria. JAMA Netw. Open 1 (4), e181449. doi:10.1001/ jamanetworkopen.2018.1449

Baird, J. K. (2009). Resistance to Therapies for Infection by Plasmodium Vivax. Clin. Microbiol. Rev. 22 (3), 508-534. doi:10.1128/CMR.00008-09

Battle, K. E., Lucas, T. C. D., Nguyen, M., Howes, R. E., Nandi, A. K., Twohig, K. A., et al. (201910195). Mapping the Global Endemicity and Clinical burden of Plasmodium Vivax, 2000-17: a Spatial and Temporal Modelling Study. Lancet 394, 332-343. doi:10.1016/S0140-6736(19)31096-7

Bennett, J. W., Pybus, B. S., Yadava, A., Tosh, d., Sousa, j. c., McCarthy, W. F., et al. (2013). Primaquine Failure and Cytochrome P-450 2D6 in Plasmodium Vivax Malaria. N. Engl. J. Med. 369 (14), 1381-1382. doi:10.1056/NEJMc1301936

Brasil, L. W., Brasil, F., Santoro, A. B., Almeida, A. C. G., Kühn, A., Ramasawmy, R., et al. (2018). CYP2D6 Activity and the Risk of Recurrence of Plasmodium Vivax Malaria in the Brazilian Amazon: a Prospective Cohort Study. Malar. J. 17 (1), 57. doi:10.1186/s12936-017-2139-7

Brasil, P., Zalis, M. G., de Pina-Costa, A., Siqueira, A. M., Júnior, C. B., Silva, S., et al. (2017). Outbreak of human malaria caused by Plasmodium simium in the Atlantic Forest in Rio de Janeiro: a molecular epidemiological investigation. Lancet Glob. Health 5 (10), e1038-e1046. doi:10.1016/ S2214-109X(17)30333-9

Cassiano, G. C., Santos, E. J. M., Maia, M. H. T., Furini, A. d. C., Storti-Melo, L. M., Tomaz, F. M. B., et al. (2015). Impact of Population Admixture on the Distribution of Immune Response Co-stimulatory Genes Polymorphisms in a Brazilian Population. Hum. Immunol. 76 (11), 836-842. doi:10.1016/ j.humimm.2015.09.045

Cavasini, C. E., de Mattos, L. C., Couto, Á. A. D. A., Couto, V. S. D. A., Gollino, Y., Moretti, L. J., et al. (2007). Duffy Blood Group Gene Polymorphisms Among Malaria Vivax Patients in Four Areas of the Brazilian Amazon Region. Malar. J. 6, 167. doi:10.1186/1475-2875-6-167

Chowbay, B., Zhou, S., and Lee, E. J. (2005). An Interethnic Comparison of Polymorphisms of the Genes Encoding Drug-Metabolizing Enzymes and Drug Transporters: Experience in Singapore. Drug Metab. Rev. 37 (2), 327-378. doi:10.1081/dmr-28805

Crews, K. R., Gaedigk, A., Dunnenberger, H. M., Leeder, J. S., Klein, T. E., Caudle, K. E., et al. (2014). Clinical Pharmacogenetics Implementation Consortium,Clinical Pharmacogenetics Implementation Consortium Guidelines for Cytochrome P450 2D6 Genotype and Codeine Therapy: 2014 Update. Clin. Pharmacol. Ther. 95 (4), 376-382. doi:10.1038/clpt.2013.254

da Silva Silveira, V., Canalle, R., Scrideli, C. A., Queiroz, R. G., Bettiol, H., Valera, E. T., et al. (2009a). Polymorphisms of Xenobiotic Metabolizing Enzymes and DNA Repair Genes and Outcome in Childhood Acute Lymphoblastic Leukemia. Leuk. Res. 33 (7), 898-901. doi:10.1016/ j.leukres.2008.12.006

Daher, A., Aljayyoussi, G., Pereira, D., Lacerda, M. V. G., Alexandre, M. A. A., Nascimento, C. T., et al. (2019). Pharmacokinetics/pharmacodynamics of Chloroquine and Artemisinin-Based Combination Therapy with Primaquine. Malar. J. 18 (1), 325. doi:10.1186/s12936-019-2950-4

Dorji, P. W., Tshering, G., and Na-Bangchang, K. (2019). CYP2C9, CYP2C19, CYP2D6, and CYP3A5 Polymorphisms in South-East and East Asian Populations: A Systematic Review. J. Clin. Pharm. Ther. 44, 508-524. doi: $10.1111 /$ jcpt.12835

Friedrich, D. C., Genro, J. P., Sortica, V. A., Suarez-Kurtz, G., de Moraes, M. E., Pena, S. D. J., et al. (2014). Distribution of CYP2D6 Alleles and Phenotypes in the Brazilian Population. PLoS One 9 (10), e110691. doi:10.1371/ journal.pone.0110691
Gomes, M. d. S. M., Vieira, J. L. F., Machado, R. L. D., Nacher, M., Stefani, A., Musset, L., et al. (2015). Efficacy in the Treatment of Malaria by Plasmodium Vivax in Oiapoque, Brazil, on the Border with French Guiana: the Importance of Control over External Factors. Malar. J. 14, 402-409. doi:10.1186/s12936015-0925-7

Griman, P., Moran, Y., Valero, G., Loreto, M., Borjas, L., and Chiurillo, M. A. (2012). CYP2D6 Gene Variants in Urban/admixed and Amerindian Populations of Venezuela: Pharmacogenetics and Anthropological Implications. Ann. Hum. Biol. 39 (2), 137-142. doi:10.3109/ 03014460.2012 .656703

He, X., Pan, M., Zeng, W., Zou, C., Pi, L., Qin, Y., et al. (2019). Multiple Relapses of Plasmodium Vivax Malaria Acquired from West Africa and Association with Poor Metabolizer CYP2D6 Variant: a Case Report. BMC Infect. Dis.;19(1):704. 9. doi:doi:10.1186/s12879-019-4357-9

Hoskins, J. M., Marsh, S., and McLeod, H. L. (2005). Comment on "A Frameshift Mutation and Alternate Splicing in Human Brain Generate a Functional Form of the Pseudogene Cytochrome P4502d7 that Demethylates Codeine to Morphine", J Biol Chem 279: 27383-27389. Drug Metab. Dispos 33 (10), 1564-1566. doi:10.1124/dmd.105.005736

Kohlrausch, F. B., Gama, C. S., Lobato, M. I., Belmonte-de-Abreu, P., Gesteira, A., Barros, F., et al. (2009). Molecular Diversity at the CYP2D6locus in Healthy and Schizophrenic Southern Brazilians. Pharmacogenomics 10 (9), 1457-1466. doi:10.2217/pgs.09.76

Lana, R., Nekkab, N., Siqueira, A. M., Peterka, C., Marchesini, P., Lacerda, M., et al. (2021). The Top 1\%: Quantifying the Unequal Distribution of Malaria in Brazil. Malar. J. 20 (1), 87. doi:10.1186/s12936-021-03614-4

LLerena, A., Naranjo, M. E. G., Rodrigues-Soares, F., Penas-LLedó, E. M., Fariñas, H., and Tarazona-Santos, E. (2014). Interethnic Variability of CYP2D6 alleles and of Predicted and Measured Metabolic Phenotypes across World Populations. Expert Opin. Drug Metab. Toxicol. 10 (11), 1569-1583. doi: $10.1517 / 17425255.2014 .964204$

Machado, R. L. D., Póvoa, M. M., Calvosa, V. S. P., FerreiraRossit, M. U. A. R. B., Rossit, A. R. B., dos Santos, E. J. M., et al. (2004). Genetic Structure ofPlasmodium falciparumPopulations in the Brazilian Amazon Region. J. Infect. Dis. 190 (9), 1547-1555. doi:10.1086/424601

Moreno, N., Flores-Ângulo, C., Villegas, C., and Mora, Y. (2016). CYP2D6 Variability in Populations from Venezuela. Drug Metab. Pers Ther. 31 (4), 181-189. doi:10.1515/dmpt-2016-0023

Naranjo, M. E. G., de Andrés, F., Delgado, A., Cobaleda, J., Peñas-Lledó, E. M., and LLerena, A. (2016). High Frequency of CYP2D6 Ultrarapid Metabolizers in Spain: Controversy about Their Misclassification in Worldwide Population Studies. Pharmacogenomics J. 16 (5), 485-490. doi:10.1038/tpj.2016.47

Oliveira-Ferreira, J., Lacerda, M. V., Brasil, P., Ladislau, J. L., Tauil, P. L., and Daniel-Ribeiro, C. T. (2010). Malaria in Brazil: an Overview. Malar. J. 9, 115. doi:10.1186/1475-2875-9-115

Pena, S. D. J., Di Pietro, G., Fuchshuber-Moraes, M., Genro, J. P., Hutz, M. H., Kehdy, F. d. S. G., et al. (2011). The Genomic Ancestry of Individuals from Different Geographical Regions of Brazil Is More Uniform Than Expected. PLoS One 6 (2), e17063-16. doi:10.1371/ journal.pone.0017063

Pybus, B. S., Marcsisin, S. R., Jin, X., Deye, G., Sousa, J. C., Li, Q., et al. (2013). The Metabolism of Primaquine to its Active Metabolite Is Dependent on CYP2D6. Malar. J. 12, 212. doi:10.1186/1475-2875-12-212

Rodrigues-Soares, F., Peñas-Lledó, E. M., Tarazona-Santos, E., Sosa-Macías, M., Terán, E., López-López, M., et al.RIBEF. Ibero-American Network of Pharmacogenetics and Pharmacogenomics (2020). Genomic Ancestry, CYP2D6, CYP2C9, and CYP2C19 Among Latin Americans. Clin. Pharmacol. Ther. 107 (1), 257-268. doi:10.1002/cpt.1598

Salles, P. F. (2020). Variabilidade Do CYP2D6 em cinco municípios endêmicos de malária por Plasmodium vivax na Amazônia brasileira, [dissertation/master's thesis], Niterói (RJ): Federal Fluminense University.

Silveira, V. D. S., Canalle, R., Scrideli, C. A., Queiroz, R. G., Bettiol, H., and Valera, E. T. (2009a). Polymorphisms of Xenobiotic Metabolizing Enzymes and DNA Repair Genes and Outcome in Childhood Acute Lymphoblastic Leukemia. Leuk Res. 33 (7), 898-901. doi:10.1016/j.leukres.2008.12.006

Silveira, V. D. S., Canalle, R., Scrideli, C. A., Queiroz, R. G. d. P., and Tone, L. G. (2009b). Polymorphisms in Genes Encoding Drugs and Xenobiotic 
Metabolizing Enzymes in a Brazilian Population. Biomarkers 14 (2), 111-117. doi:10.1080/13547500902767294

Silvino, A. C., Costa, G. L., Araújo, F. C., Ascher, D. B., Pires, D. E. V., Fontes, C. J. F., et al. (2016). Variation in Human Cytochrome P-450 Drug-Metabolism Genes: A Gateway to the Understanding of Plasmodium vivax Relapses [published correction appears in PLoS One. 2018 Feb 1;13(2):e0192534]. PLoS One 11 (7), e0160172. doi:10.1371/journal.pone.0160172

Silvino, A. C. R., Kano, F. S., Costa, M. A., Fontes, C. J. F., Soares, I. S., de Brito, C. F. A., et al. (2020). Novel Insights into Plasmodium Vivax Therapeutic Failure: CYP2D6 Activity and Time of Exposure to Malaria Modulate the Risk of Recurrence. Antimicrob. Agents Chemother. 64 (5), e02056-19. doi:10.1128/AAC.02056-19

Tarazona-Santos, E., Castilho, L., Amaral, D. R. T., Costa, D. C., Furlani, N. G., Zuccherato, L. W., et al. (2011). Population Genetics of GYPB and Association Study between $G Y P B \times S / s$ Polymorphism and Susceptibility to $P$. Falciparum Infection in the Brazilian Amazon. PLoS One 6 (1), e16123-24. doi:10.1371/journal.pone.0016123

Toscano, C., Klein, K., Blievernicht, J., Schaeffeler, E., Saussele, T., Raimundo, S., et al. (2006). Impaired Expression of CYP2D6 in Intermediate Metabolizers Carrying the ${ }^{\star} 41$ Allele Caused by the Intronic SNP 2988G >A: Evidence for Modulation of Splicing Events. Pharmacogenet Genomics 16 (10), 755-766. doi:10.1097/01.fpc.0000230112.96086.e0

Wernsdorfer, W. H., and Noedl, H. (2003). Molecular Markers for Drug Resistance in Malaria: Use in Treatment, Diagnosis and Epidemiology. Curr. Opin. Infect. Dis. 16 (6), 553-558. doi:10.1097/00001432-200312000-00007
Zhou, S.-F. (2009). Polymorphism of Human Cytochrome P450 2D6 and its Clinical Significance. Clin. Pharmacokinet. 48 (11), 689-723. doi:10.2165/ 11318030-000000000-00000

Conflict of Interest: The authors declare that the research was conducted in the absence of any commercial or financial relationships that could be construed as a potential conflict of interest.

Publisher's Note: All claims expressed in this article are solely those of the authors and do not necessarily represent those of their affiliated organizations, or those of the publisher, the editors and the reviewers. Any product that may be evaluated in this article, or claim that may be made by its manufacturer, is not guaranteed or endorsed by the publisher.

Copyright $\odot 2021$ Salles, Perce-da-Silva, Rossi, Raposo, Ramirez Ramirez, Pereira Bastos, Pratt-Riccio, Cassiano, Baptista, Cardoso, Banic and Machado. This is an open-access article distributed under the terms of the Creative Commons Attribution License (CC BY). The use, distribution or reproduction in other forums is permitted, provided the original author(s) and the copyright owner(s) are credited and that the original publication in this journal is cited, in accordance with accepted academic practice. No use, distribution or reproduction is permitted which does not comply with these terms. 